\title{
Star Wars or Strategic Defense Initiative: What's in a name?
}

Anette Stimmer, University of Oxford

\begin{abstract}
Popular culture can influence debates over security policy. This article studies the use of Star Wars in the debate over Reagan's Strategic Defense Initiative (SDI). The term Star Wars was widely used to refer to SDI during debates in the 1980s. Scholars have pointed to both disabling and enabling effects of popular culture on political debates. This article refines these effects and introduces a third effect that comes from the widespread use of popular culture: a neutralizing effect that turns popular culture references into descriptive short-hands. This contributes to our understanding of why popular culture is or is not used as a framing device, and how it is used and perceived by decision-makers. I rely on content analysis of newspaper articles, congressional records, and political speeches and incorporate findings from elite interviews and the norm literature to conduct my analysis. I find that critics capitalized on linkages between the movie franchise and the policy to frame Reagan's missile defense system as Star Wars, and to criticize his policy proposal. This science-fictionalization soon constituted the socio-political context surrounding Reagan's missile defense initiative. Most decision-makers perceived the Star Wars label to have a disabling effect, as it cast doubt on the viability and desirability of SDI. Opponents initially tried to mobilize this effect, whereas most proponents argued against the label or refrained from using it. Few tapped into the enabling potential of Star Wars to communicate the potential benefits of SDI. The introduction of the professional term SDI helped proponents mitigate science-fictionalization in expert settings, while among the public the widespread use of the Star Wars label neutralized its meaning and turned it into a descriptive short-hand.
\end{abstract}

\section{Introduction}

"Boy, I saw Rambo last night... Now I know what to do next time this happens," Reagan said when American hostages were released in Lebanon (quoted in Krämer 2012, 65-66). The actor-president's speeches, in which he often employed movie references, reflected his fondness for film (FitzGerald 2000; Krämer 2012). However, when it came to his favorite project - a space-based missile defense system, dubbed Star Wars ${ }^{1}$ - Reagan strongly opposed the popular culture reference: "I wish I could catch the person that first gave it that name," he said, "because it's more about peace than it is about wars" (1986. Speech, October 16).

Even movie enthusiasts like Ronald Reagan sometimes fail to sanction the use of popular culture to promote their preferred courses of action. This trend may go back to the potential of popular culture to have both an enabling effect in communicating policies by tapping into common knowledge (Neumann and Nexon 2006), and a disabling effect by inviting trivialization and ridicule (Carpenter 2016; Wendt and Duvall 2008). Yet, we currently know little about actors' understandings of these effects, and about how they interact. Studying the use of Star Wars in the debate over Reagan's Strategic Defense Initiative (SDI) promises to shed light on these questions: Why do some actors use popular culture as a framing device, while others do not? And, how does the effect of popular culture change over time?

\footnotetext{
${ }^{1}$ I use Star Wars to refer to the name that was given to Reagan's missile defense policy and Star Wars to refer to the movie franchise.
} 
The debate over Star Wars is well-suited to exploring these questions. While Reagan's missile shield never fully materialized, ${ }^{2}$ SDI dominated US security policy debate in the 1980s. Since SDI was commonly referred to as Star Wars, the science fiction reference was widely used over an extended period. This allows us to study who used the Star Wars label, how they used it, whether opponents and proponents used it differently, and how this changed over time. I rely on content analysis of newspaper articles, congressional records and political speeches to trace the use of the Star Wars analogy during the Reagan administration. Further, I draw on elite interviews to add important context and interpretive clarity.

I argue that movies such as Star Wars can accommodate multiple meanings, hence there is a potential for popular culture to have both an enabling and a disabling effect on political behavior and communication. I show that opponents initially linked Star Wars to Reagan's missile shield. Because the viability of Reagan's vision was doubtful, the Star Wars analogy invited trivialization and ridicule and thus "science-fictionalized" (Carpenter 2016, 59) the policy. This science-fictionalization then constituted the socio-political context in which politicians operated. Some actors tapped into its enabling or disabling effects, whereas others consciously argued against the science fiction analogy or refrained from using it. Their reaction depended on whether they considered the use of popular culture helpful in the pursuit of their goals. In expert settings, the introduction of the more professional term Strategic Defense Initiative (SDI) mitigated the science-fictionalization. In public use, the success of the Star Wars label eventually led to the undoing of these effects, as its widespread use neutralized the term.

This article contributes to explanatory research (Carpenter 2016) into the role of popular culture in International Relations (IR). It refines our understanding of why popular culture is or is not used in political discourse, by whom and for what motivations, and shows that the widespread use of a popular culture reference can neutralize the meaning of a particular term. Furthermore, I illustrate that there is potential for cross-fertilization between the literatures on popular culture and norms when both study the framing of political options. Just like norms, popular culture can have different meanings, which raises the question of what affects meaning-in-use. Moreover, popular culture can be a useful framing device when opposing the emergence of new norms.

\footnotetext{
${ }^{2}$ The space-based components of SDI turned out to be technologically problematic. George H.W. Bush and Bill Clinton refocused missile defense development and spending towards more limited, ground-based systems (FitzGerald 2000, 479; Pifer 2015). While shorter range, ground-based missile defense systems such as Theater High Altitude Area Defense (THAAD) are in place today, these are a very limited version of what Reagan had planned in reach and scope, and have not achieved the vision at the core of SDI, which involved "rendering these nuclear weapons impotent and obsolete" (Reagan, Speech, March 23, 1983).
} 
I begin by describing the relationship between global security, popular culture, and Reagan's Star Wars. Second, I show that the norm literature's insights into the contestation, flexible meanings, and tactics of proponents and opponents help to refine the effects of popular culture references. Third, I discuss how the science-fictionalization dynamic that acompanied the Star Wars label affected whether and how political actors used Star Wars analogies. Fourth, I illustrate that the widespread use of the Star Wars label neutralized its otherwise disabling effect for the public, and analyze what led to this widespread use.

\section{The role of popular culture and normative frames in security debates}

Research on global security, popular culture and Reagan's Star Wars

Science fiction and global security are realms of fantasy and policy that are influenced by and influencing of popular culture. ${ }^{3}$ Studying the relationship between security issues and science fiction thus promises to make an important contribution to global security studies. Global security studies accommodate a wider variety of actors and mechanisms than orthodox approaches to security studies. Moving beyond a singular focus on the military capabilities of states, Goddard and Nexon (2016), amongst others, include sub-state actors in analyses of security and refer to cultural instruments as important mechanisms in global power politics. Moreover, Der Derian's (2009, 256) "Military-Industrial-Media-Entertainment-Network" illustrates the nexus between (popular) culture and security. During World War II, for example, the War Department and Hollywood bundled resources to produce close to 2,500 war movies to secure the support of the population (ibid., 240). Hence, popular culture has been considered an important instrument to bolster power and security. Within popular culture research, scholars regard science fiction as a particularly influential genre as it plays on estrangement (Weldes 2003; Kiersey and Neumann 2013; Carpenter 2016), allowing us to look at the real-world from a distance while remaining grounded in reality.

Fantasy and reality are not only blended in works of science fiction, but also sometimes in security policy debates. Reagan's SDI serves as an example. Reagan (1983. Speech, March 23) proposed to move away from fear of nuclear war and mutually assured destruction by developing a space-based anti-missile shield that "could intercept and destroy strategic ballistic missiles before they reached our own soil and that of our allies." Yet, missile defense,

${ }^{3}$ I thank an anonymous reviewer for this formulation. 
particularly Reagan's vision of a nation-wide space shield, is technologically difficult to realize, if not unfeasible, as well as expensive (FitzGerald 2000; Boyer 2011; Krämer 2012; Reiss 1992). Due to the short flight time of Inter-Continental Ballistic Missiles, interception is extraordinarily difficult- some compare it to the difficulty of hitting a bullet with another bullet (Lockheed n.d.). The technological unreliability of missile defense means that defenses can be overwhelmed with large arsenals (FitzGerald 2000, 249). Despite these difficulties, comprehensive missile defense was a popular fantasy as it promised protection from nuclear war. Whether missile defense provides protection depends not only on technological and budgetary realities. We must also consider whether enemies are deterred by the potential risk of a potent defense or whether they see such a missile shield as an offensive weapon that allows for a military first strike without consequences (Boyer 2011, 207; Pifer 2015). Thus, whether missile defense is a reality or a fantasy not only depends on facts, but also on how others interpret and react to it. Popular culture can reveal and influence the blending of fact and fiction in security debates. I demonstrate this through an analysis of the role of Star Wars in the debate over SDI.

IR scholars have adopted two different approaches - interpretive and explanatory (Carpenter 2016 ) - to explore the role of science fiction and fantasy in real-world politics. We can also map previous studies of the relationship between Star Wars and SDI onto this distinction. I build on and refine the explanatory approach by analyzing why some actors used Star Wars as a framing device in the debate over SDI, whereas others refrained from doing so.

Interpretive scholars analyze science fiction texts and movies to learn more about how popular culture (re)produces power relations, societal values, and political sentiments (Neumann and Nexon 2006). When it comes to Reagan's Star Wars, Meyer $(1992,99)$ engages in interpretive analysis of the science fiction epics to show that unlike what Star Wars proponents claimed, the "Star Wars films suggest another reading that is far more skeptical of SDI's promises." Thus, interpretive approaches see works of science fiction as a reflection of, or commentary on, real-world issues. Some interpretive scholars claim that works of science fiction and fantasy participate in meaning production of what counts as normal and what does not (Shepherd 2013; Griffin 2015). Interpretive scholars use works of science fiction as their 'data' (Neumann and Nexon 2006, 13), by unpacking and critically reflecting on the content of works of science fiction to uncover their influence on society. 
Meaning production is not the only way through which popular culture can influence political reality (Weldes 2003; Neumann and Nexon 2006; Carpenter 2016). An explanatory approach is emerging that examines how science fiction "impacts on real-world political action, events or categories of meaning, or on non-fictional representations of those events and meanings" (Carpenter 2016, 55). Explanatory research shows that popular culture not only diffusely influences the real-world by shaping what counts as appropriate behavior, but also more directly shapes the calculations of political actors and the content of political speeches. Popular culture can have a causal or constitutive effect on political processes and first-order representations such as political speeches and newspaper articles, which "directly represent political events" (Neumann and Nexon 2006, 7).

Some scholars claim that Reagan's role in the movie Murder in the Air, which includes a fictional secret weapon that makes the US invincible, inspired him to pursue SDI (Talbott 1988, 188-189; FitzGerald 2000, 22-23). However, they also discuss other possible causes such as his dislike for nuclear weapons, the nuclear freeze movement, and the influence of physicist Edward Teller. Unlike causal inquiries, constitutive studies do not treat popular culture as having a direct impact on decisions: its impact is more diffuse. Building on constructivist insights about the role of ideas in constituting political reality (Wendt 1992; Katzenstein 1996), scholars argue that popular culture shapes the way actors think about a policy or communicate it. The focus is on perceptions rather than on causation. Popular culture may not directly cause actions, attitudes or outcomes, but because decision-makers think it matters, popular culture informs or enables certain actions.

Neumann and Nexon (2006) argue that popular culture can have an "informing" effect by predisposing societies to think in specific ways, since it "provides diffuse knowledge that people bring to bear on political issues" (p. 18). Star Trek's influence on the American space policy is an example. This "informing" effect can lead to an "enabling" effect, where popular culture "may lend metaphorical strength to the appeal of a certain policy" (p. 18). By tapping into popular science fiction narratives, political actors can communicate their policies better and build support for their goals.

In her study of the campaign to stop killer robots, Carpenter (2016) illustrates that popular culture may also have a disabling effect. She shows that while the use of killer robot imagery was a hook that enabled conversations and media coverage about fully autonomous weapons systems, the science-fictionalization of the topic led to trivialization and ridicule in the media, 
disabling campaigners. Campaigners tried to counteract the media's ridicule with substance and by poking fun at their own use of robot imagery to de-science-fictionalize the topic. Wendt and Duvall (2008) also detected this science-fictionalization in the taboo against studying UFOs scientifically.

Carpenter $(2016,64)$ calls for more research to sharpen the conceptualization of informing effects, and to shed more light onto the relationship between science-fictionalization and descience-fictionalization. This article seeks to contribute to the refinement of the explanatory approach. The debate over SDI is well-suited for analyzing these questions because Star Wars both disabled and enabled actors and their communication of SDI and the Star Wars label figured in public debate for a prolonged timeframe.

A systematic analysis of the role Star Wars played in the debate over SDI also contributes to the literature on Reagan's Star Wars. While scholars mention that SDI was dubbed Star Wars, quote initial reactions to the label, and cite Star Wars references, a systematic analysis of the use of Star Wars and its effect is missing. Most volumes on Reagan's SDI focus on describing the origins, discussion, and impact of SDI (Talbott 1988; Reiss 1992; FitzGerald 2000; Boyer 2011). The role of Star Wars specifically is not analyzed in detail. Those who focus on the role of Star Wars primarily look at symbols such as cartoons (Linenthal 1989) or fail to sufficiently ground their analysis in empirics and theory (Desloge 2012; Krämer 2012). Desloge (2012) and Krämer (2012) chronicle well why SDI was called Star Wars, and how Star Wars was used, but their assertions on the impact of the Star Wars label and on Reagan's stance towards it are not sufficiently documented. A theoretically and empirically grounded analysis of the effect the Star Wars frame had on key actors and on the debate addresses these shortcomings.

\section{Framing with norms and popular culture}

While the role of popular culture in enabling and disabling political actions is a relatively new research field, the literature on norms has a longer history of studying framing when norms are promoted or opposed. Framing refers to strategic efforts to generate shared understandings and to legitimate certain types of actions (Benford and Snow 2000, 614-615). Popular culture as a framing device, however, has not been studied in detail in the norm literature. Therefore, there is considerable potential for cross-fertilization between these two literatures.

Popular culture can be compared to norms when studying the framing of policy choices. Star Wars introduced a new norm or "standard of appropriate behavior" (Finnemore and Sikkink 
1998, 891). The idea of rendering nuclear weapons "impotent and obsolete" (Reagan, Ronald.1983. Speech, March 23) through a space-based defensive shield over the United States contested the norm that guided US security policy in the 1960s and 1970s: Mutually Assured Destruction, (MAD) (Boyer 2011; Krämer 2012). This norm was well established in international relations since it under-girded the 1972 Anti-Ballistic Missile (ABM) Treaty, which only allowed for two missile defense systems and left the majority of the US's and Soviet Union's population vulnerable to attack (Boyer 2011). ${ }^{4}$ With SDI in place, destruction would no longer be mutually assured.

Even if popular culture was not used to contest an existing norm, the findings of the norm literature can be useful. No matter whether a norm or a policy are promoted or opposed through popular culture, the end goal is to influence political action and behavior. Thus, we would not expect the tactics that actors use to be fundamentally different when a policy rather than a norm - is the the subject of contention. Most scholars who study the tactics actors use to promote or oppose norms assume that actors act strategically. They also assume that tapping into existing notions of appropriateness is key, blending insights from constructivism and rationalism (Bloomfield 2016; Bob 2012; Schimmelfennig 2001; Finnemore and Sikkink 1998). When it comes to framing, the ability to show that the idea is a close 'cultural match' to similar, existing discourses and perceptions is important (Price 1998; Checkel 1999; Busby 2007); what audiences are already familiar with and have already accepted is difficult to argue against. Finding linkages thus contributes to successful framing. Popular culture can provide familiar notions onto which to graft, facilitating the generation of shared understandings.

According to Neumann and Nexon (2006), popular culture can have a "naturalizing effect," which makes certain ways of looking at an issue appear as though something is "just the way things are'” (p. 19). However, as Carpenter $(2016,57)$ points out, claims about the naturalizing effect of popular culture tend to be sweeping. They fail to take into account that different people may read different things into cultural artifacts. Star Wars, for instance, can be read as a warning against over-reliance on technology - since Death Stars keep exploding - but also as a symbol of the American can-do spirit in which good triumphs over evil. This latter interpretation grafts well onto the reality of the Cold War between the US and USSR. Thus, Star Wars could both enable and disable the communication of SDI's benefits. Similarly, norm scholars have started to see norm meaning as dynamic "works-in-progress" (Krook and True 2012, 104), rather than

\footnotetext{
${ }^{4}$ In comparison to the preventive self-defense norm on which SDI rests, MAD was institutionalized in international law at the time. Hence, I consider it to be the status quo norm, which is challenged by the Reagan administration with SDI. The legal discussion also centered on the ABM treaty, that is whether a broad or narrow reading of Art. $V$ of the ABM Treaty which allows or does not allow for development and testing of space-based weapons defense systems is correct (Kennedy 1986).
} 
as static. The meaning of norms can change over time due to the ambiguity of language, or unexpected events and tensions, which open up opportunities to reconstruct meaning (Wiener and Puetter 2009; Sandholtz 2008; Krook and True 2012).

Some norm scholars draw on Wittgenstein's $(1973,43)$ insight that "the meaning of a word is its use in language." That is to say, words do not have predetermined meanings. It therefore becomes necessary to study how a term is used in different contexts in order to learn about its different meanings, and the salience of those meanings. As a result, Wiener and Puetter $(2009,15)$ argue that "how norms are enacted depends first and foremost on the specific contextual conditions." The same applies to popular culture. Popular culture is a vehicle through which to communicate notions of (in)appropriateness, but we cannot only infer the effect of using popular culture from works of popular culture themselves. Contextual factors such as where the debate occurs and how popular culture is used also matter.

Bloomfield (2016) argues that opponents of norm change enjoy significant tactical advantages, particularly if the contested norm is entrenched, as was MAD in the 1980s (p. 323-324). Historical, sociological, and bounded rationality approaches all conclude that there is a strong bias towards existing norms and institutions because they involve less risk and have been continuously reinforced (Thelen 1999; Legro 2000; Jupille, Mattli, and Snidal 2013). To successfully challenge the status quo, norm entrepreneurs (proponents of SDI) must show that there is a normative problem with the institutionalized status quo (MAD), and present a viable solution (Bloomfield 2016, 322-323). Those who favor the status quo, on the other hand, must discredit these claims. Popular culture can help both sides in communicating their views.

SDI proponents questioned the underlying morality of MAD. Efforts to prevent bodily harm such as SDI are a persuasive notion of appropriateness for norm entrepreneurs to tap into, because they are widely perceived as legitimate (Finnemore and Sikkink 1998, 907). As Americans have generally lived securely and free from outside attacks, the belief that defense is possible is widespread (Reiss 1992, 159). As this hope of protection rather than retaliation underlies SDI, it had popular appeal. Opponents, on the other hand, questioned the normative desirability of this hopeful vision by using Star Wars to communicate that a space-based missile defense system may increase the danger of an actual "star wars." 
Proponents also had to show that SDI was a viable solution. Bloomfield $(2016,323)$ argues that a popular tactic of opponents of norm change is "to pick holes in the new norms, and/or tag the norm entrepreneurs as idealist, naïve dreamers." This is exactly what sciencefictionalization is about. Popular culture can be a potent way of tagging proponents of norm change as "naïve dreamers," thus inviting in ridicule and trivialization. Carpenter (2016) traces this disabling effect back to understandings of popular culture as a fantasy or futuristic scenario that is unrealistic.

The disabling effect's function is to mock political or normative initiatives. However, the use of science fiction references does not have this effect per se. It also requires a public perception that the proposal being questioned through comparison to works of science fiction is currently unviable (Bloomfield 2016, 323), or at the very least not ripe for debate (Carpenter 2016, 59). SDI opponents could therefore use Star Wars to criticize the initiative given that Reagan's announcement came as a surprise, and the missile shield's very viability was questionable. The science-fictionalization that came with the Star Wars label had tangible effects: decisionmakers thought carefully about whether its use would help or hinder their goals.

While the Star Wars label initially led to the science-fictionalization of SDI, the direct meaning of Star Wars as a ridiculous and dangerous space fantasy will not necessarily always prevail. Since the disabling effect depends on the perception that the proposal is unviable or normatively undesirable, changing perceptions of viability or desirability can reverse this effect. Furthermore, while the general meaning of works of science fiction as fantasy may have a mocking effect, the specific content of works like Star Wars can encompass multiple meanings. Thus, depending on the framing, actors can use Star Wars both to enable or disable communication of a policy or norm.

Most SDI proponents disliked the Star Wars label because they perceived it to be disabling. However, the widespread media use of the term led to an additional, neutralizing effect. Specifically, the widespread use neutralized the Star Wars label's meaning and stripped it of negative connotation. Star Wars became a purely descriptive vernacular that the public associated with Reagan's space-based missile defense system. Linkages between Star Wars and the policy itself helped to simplify a complex issue, and contributed to the popularity of the Star Wars frame. Moreover, the Reagan administration's failure to introduce a (catchy) alternative name and changing perceptions of the viability of missile defense were key to keeping Star Wars in the public debate. As I will illustrate, linkages between the label and the theory, changing perceptions of viability and the failure to introduce an official name in a timely manner also contributed to the widespread use and thus neutralization of the big bang label for the theory of the origin of the universe in public use. This finding increases confidence in the explanatory value of these three factors. 
Notably, the Star Wars label only became a neutral, descriptive short-hand in the mind of the public. To this day, many inner-circle proponents of SDI consider the Star Wars label mocking and trivializing. This differing audience reception was particularly evident in the ways that different actors employed the label. For instance, while the Star Wars label was common in newspaper articles and in the public speeches of political opponents, the technical term SDI was more common in congressional speeches where the goal was to persuade peers rather than publics. Thus, only when actors consider science fiction references helpful in communicating their viewpoints will they use them in their efforts to persuade others.

\section{Star Wars or Strategic Defense Initiative: What's in a name?}

The debate over Star Wars illustrates the enabling, disabling, and neutralizing effects that come with the use of science fiction in political debate. Since SDI - commonly referred to as Star Wars - dominated US security policy from 1983 to 1988, the case represents an instance of prolonged use of popular culture in political debate. This makes it an ideal case for tracing the effect that science fiction as a concept, and Star Wars specifically, had on the preferences and strategies of proponents and opponents of Reagan's missile shield.

I draw on two sources of primary data in my analysis. First, I performed a content analysis of archival records such as newspaper articles, political speeches and Congressional Records to trace how the use and effect of Star Wars in the debate over SDI changed over time. Second, I conducted semi-structured interviews with SDI proponents and opponents (congressional representatives and senior Reagan-administration officials) to provide important context to the content analysis. The interviews help to establish why popular culture was or was not used in political discourse and how decision-makers perceived its effect.

I show that opponents used linkages between the characteristics of Star Wars and Reagan's missile shield to science-fictionalize the policy. This science-fictionalization then constituted the socio-political context in which politicians operated. I also find that SDI proponents and opponents consciously reflected on whether using the Star Wars frame would help or hinder their goals. The widespread use of Star Wars eventually neutralized its meaning and turned it into a descriptive short-hand for the public. Nevertheless, the Star Wars label was never fully embraced by most inner-circle proponents, who succeeded in introducing the SDI label as the serious, expert term.

\section{Why Star Wars?}

By the early 1980s, MAD was under attack from different circles: not only Cold War hawks 
who preferred military superiority over the USSR, but also doves who opposed MAD due to its reliance on fear of retaliation. The recession of 1981-82 increased unemployment and the budget deficit, creating opposition to increases in defense spending (Krämer 2012). A nuclear freeze movement gained traction in 1982-83: hundreds of thousands of people participated in rallies and fifteen states passed resolutions for a moratorium on nuclear weapons research, deployment, and testing while arms control talks were under way (Boyer 2011, 200-201).

Opposition to his defense budget, low approval ratings, and the strong missile defense advocacy of physicist Edward Teller and conservative Republicans prompted Reagan to think seriously about greater reliance on defense. This combination of factors prompted deeper research into the topic, culminating in the 1983 "Star Wars" speech (Boyer 2011). This speech took most by surprise, as only a few senior officials were aware of its existence and there was no detailed plan to put the idea into action. Reagan perceived the policy to build a space-based missile defense system that would protect the entire US from nuclear attack as a means to neutralize the nuclear freeze movement, and to justify large defense budgets (FitzGerald 2000; Boyer 2011).

Reagan's principled beliefs were a more deep-seated, underlying cause for pushing a new missile defense system. Reagan disliked nuclear weapons and dreamt of a world free of them. Private communication, diaries, public statements, and advisors' testimonies all support this conclusion (Krämer 2012; Boyer 2011; FitzGerald 2000). Press secretary Marlin Fitzwater recounts that Reagan commented on the presence of nuclear freeze protesters in front of the White House by saying: "Freeze them? I wanna get rid of them" (Fitzwater, Marlin. 2017. Interview with author, October 31). The president believed that space-based missile defense was the best way to achieve this. Hence, Reagan refused to use the policy as a bargaining chip in negotiations with the Soviet Union. His reluctance to use SDI to gain major concessions, for example at Reykjavik summit, also reflects his moral commitment to SDI (Boyer 2011, 215). Reagan thus acted as a norm entrepreneur, advocating for comprehensive missile defense and the self-defense norm that underpins it and contested MAD.

Experts often conjur one story in particular to explain what prompted Reagan's commitment to nuclear defense. ${ }^{5}$ Specifically, a visit to the North American Air Defense Command (NORAD) in 1979 is said to have made him concerned about US safety. In a simulation, Reagan saw

${ }^{5}$ Fitzwater also cited Reagan's NORAD visit as explanation for SDI, saying: "I'm not even sure it's true, but I will give it to you anyway because it's the popular version." (Fitzwater, Marlin. 2017. Interview with author, October 31). 
that nothing could be done if a missile warhead was flying towards an American city. FitzGerald $(2000,20-21)$ uses the NORAD visit to illustrate that Reagan often blended myth and reality in his speeches, since it is unlikely that Reagan was not aware of the US's reliance on deterrence eighteen months before becoming president. Reagan's acting career in Hollywood deeply influenced him. He was an actor-president, who liked to tell a good story and frequently referenced movies (FitzGerald 2000, 21-29; Krämer 2012, 65-68). Successful frames link to existing discourses and perceptions (Price 1998; Checkel 1999; Busby 2007), and Reagan's personality and rhetorical style invited associations with movies in particular. But why Star Wars?

The science-fiction franchise was at the forefront of the public's mind at the time: the first Star Wars movie, A New Hope (1977), was the highest grossing movie at the US box office at the time (Box Office Mojo 2017a), and is still the second highest grossing movie of all time (Box Office Mojo 2017b). The sequel, The Empire Strikes Back (1980), became the highest grossing movie in 1980 (Box Office Mojo 2017c). The unprecedented high sales of movie merchandise also speak to the popularity of the two movies (Krämer 2012, 68). Furthermore, Return of the Jedi was due to come out in May 1983 and keenly anticipated (Desloge 2012).

Hence, when Reagan ascribed to the Soviet Union "the aggressive impulses of an evil empire" in March 1983 (Reagan, Ronald. 1983. Speech, March 8), commentators nicknamed his speech the "Darth Vader" speech (FitzGerald 2000, 22). While it is known that Reagan and his speechwriters did not intentionally refer to Star Wars, others made the connection. The media also linked Star Wars to space-based laser weapons for missile defense when they were first discussed in the late 1970s (Krämer 2012). Because of Star Wars' popularity, and linkages between Star Wars and Reagan's personality, space, and exotic weapons, it is of little surprise that when Reagan talked about "a new hope" and announced a space-based weapons system on March 23, 1983, it was framed Star Wars.

The use of Star Wars and reactions to it

Senator Edward Kennedy is often credited with first drawing the comparison between SDI and Star Wars (Krämer 2012; Desloge 2012; Linenthal 1989) by characterizing Reagan's vision of an impenetrable missile shield as "misleading Red-scare tactics and reckless Star Wars schemes" (Cannon 1983). The Congressional Record of the day after the announcement reveals that other opponents also used the Star Wars label to characterize Reagan's proposal as futuristic or 
reckless. ${ }^{6}$ The legislators strategically framed Reagan's idea as Star Wars because the linkages between the movie and the policy allowed them to cast doubt on the idea of a missile shield that would protect the entire US from missile attacks.

An important link between Star Wars, the science fiction genre more broadly, and Reagan's vision was that all were perceived as a fantasy - Reagan's idea of an impenetrable umbrella that would protect the US from missile attack only existed on paper and caught even most senior administration officials by surprise when he announced it. Star Wars allowed opponents to communicate viability and credibility issues, and thus to science-fictionalize the policy. Representative Weiss (D-NY), for example, tagged Reagan as a naïve dreamer when he stated that "never in my wildest dreams could I ever imagine our President taking to the national airwaves to promote a strategy of futuristic 'Star Wars' schemes as Mr. Reagan did last night." (Congressional Record March 24, 1983, 7312). Former Congressman Norm Dicks (D-WA), one of the first to use the analogy, pointed to the links between the movie and the idea of a missile shield, when describing why Reagan's vision was labelled Star Wars:

"he talked about having a space-based system in his speech on March of 1983 and so there was this very popular movie, you know, that was named Star Wars. And Reagan, of course, being an actor, you know [...] but there was also a bit of this is a pretty fantastic concept in terms of questioning whether we have the technology. You know when you do a movie you can just make it up, but this is the real deal. So, there was an immediate credibility issue" (Dicks, Norm. 2017. Interview with author, October 30).

Furthermore, the literal meaning of Star Wars also fits well with the message of opponents. Former Congressman Les AuCoin (D-OR) recounts: "Part of why we called it Star Wars was not only because it heaped ridicule on Star Wars, because it also had this offensive connotation of war, it communicated the danger" (AuCoin, Les. 2017. Interview with author, October 31). Thus, Representative Leach (R-IA) pointedly remarked that "[i]f 'Star Wars' is to remain fiction, the Earth must be protected from holocaustal weapons systems." (p. 7315) AuCoin himself called Reagan's vision a "blueprint for a 'Star Wars' military approach" (Congressional Record March 24, 1983, 7311). Taking the analogy and ridicule one step further, Congressman Downey (D-NY) remarked that "the only thing the President did not tell us last night was that the Evil Empire was about to launch the Death Star against the United States." (ibid., 7313).

Opponents played on the literal meaning of Star Wars as a fantastical and futuristic idea to be played out in the "stars" and a dangerous idea that could lead to actual "wars". Opponents

\footnotetext{
${ }^{6}$ Congressional Record March 24, 1983. See statements by Senator Byrd (D-VA), p. 7100; Senator Pryor (D-AR), p. 7145; Representative Weiss (D-NY), p. 7312; Representative Dicks (D-WA), p. 7328; Representative Aucoin (D-OR), p. 7311, Brown (D-CA), p. 7417, LaFalce (D-NY), p. 7495; and Republican Representative Leach (IA), p. 7315.
} 
regarded space-based missile defense not only as technologically unviable, but also as an offensive move: even if SDI would be effective, it could not be deployed at once, which might tempt the Soviet Union to defeat it while it could. They feared that this dynamic would lead to an arms race and nuclear war (FitzGerald 2000, 248-249). In short, the Star Wars label encapsulated the criticism of the fantastical and dangerous nature of missile defense, helping opponents question the viability and normative desirability of substituting the MAD norm with self-defense.

The Star Wars analogy resonated with the press. At a White House press briefing the day after Reagan's announcement, the Star Wars theme song blasted from a reporter's tape recorder (United Press International 1983). A few days later, the New York Times editorial (1983) was titled "Nuclear Facts, Science Fiction" and the Newsweek cover of April 4 read: "Star Wars: Will Space Be the Next Battleground?" (quoted in FitzGerald 2000, 211). Reagan's suggestion of a space-based missile defense shield soon became known as Star Wars in the press and beyond. The popular culture reference effectively reconstituted the socio-political context and influenced the way actors promoted their positions.

The disabling effect that comes with science-fictionalization can best be seen in the reactions to the Star Wars label. Unlike some scholars' reports to the contrary (Meyer 1992; Desloge 2012; Krämer 2012), Reagan, the movie enthusiast, clearly disliked the label and felt compelled to refrain from using it or to actively argue against it. ${ }^{7}$ Searching the Public Papers of Ronald Reagan for the term "Star Wars" supports this conclusion (Ronald Reagan Presidential Library 2017). A search yielded only 45 results, whereas searching for "strategic defense initiative" provided 232. Thus, Reagan rarely used the Star Wars label himself. When the Star Wars label does appear in a speech or interview, it is mostly in reference to a direct question about the Star Wars policy: Reagan then either refrains from using the term in his actual response (e.g. Reagan, Ronald. Speech, March 29, 1985 and December 11, 1987) or explains his misgivings about the label. His dislike of the analogy is clearly linked to the literal meaning of Star Wars: "They call it Star Wars; there is nothing in that, descriptive of what we are talking about," he said at a fundraising luncheon, because "[w]e're talking about a defensive shield that won't hurt people, but will knock down nuclear weapons before they can hurt people" (Reagan, Ronald. 1985. Speech, October 4). Reagan also felt that the Star Wars label led to misconceptions among members of the public. He referred specifically to an opinion poll that asked Americans about their approval of the policy, once by using the term Star Wars and once by describing it as a strategic defensive shield that could make nuclear weapons

\footnotetext{
${ }^{7}$ All my interviewees, two of them with easy access to the president, stated that Reagan disliked the Star Wars analogy or found it demeaning.
} 
obsolete (1985. Speech, October 31). Only approximately 30 percent of Americans favored Star Wars, whereas approximately 90 percent favored the strategic defensive shield, according to Reagan.

The preceding scenario illustrates the constitutive effect of popular culture: Reagan believed that the term Star Wars influenced the way people thought about his missile defense policy, and that he needed to do something about it. Opinion polls (Graham and Kramer 1986) and scholarly interpretations thereof (Reiss 1992, 163) somewhat confirm Reagan's perception. While public opinion seems to have been split on the missile defense system, there is indication that the wording of questions influenced public perceptions: when the Star Wars name was linked to danger and potential for conflict, the public tended to express more opposition. By contrast, the public was more supportive of the initiative when questions highlighted its strategic defensive aspect (Reiss 1992, 163 and Graham and Kramer 1986). These results suggest that when the Star Wars label was linked to potential pitfalls, references to popular culture had a negative impact on public opinion. This disabling effect was primarily mobilized in public discourse at the beginning of the debate.

To counteract the perceived disabling effect of the Star Wars label, proponents of Reagan's missile shield tried to substitute Star Wars' with other names. These efforts largely failed (Linenthal 1989, 15-16). Press Secretary Marlin Fitzwater recalls:

"We did talk about that, you know, shall we change the name, can we come up with a name that was so catchy that it would catch on, but it had to be more serious in the way it portrays the system and we just finally said no, there is just no way to do it. Star Wars was so ingrained in the consciousness and the news media would not give it up. We couldn't come up with an alternative that was as catchy, as fascinating as Star Wars" (Fitzwater, Marlin. 2017. Interview with author, October 31).

However, while they did not succeed in replacing references to Star Wars, proponents of Reagan's policy succeeded in introducing another name for it: Strategic Defense Initiative, or SDI in January 1984 (Reiss 1992, 73). The term SDI became the professional term in discussions around Reagan's missile defense system, and was used to communicate the defensive goal of the initiative. Star Wars, on the other hand, stuck as the popular term for the policy:

"Star Wars was the term that was used by layman, by common people, particularly by the press, reporting writing about it, used Star Wars, because it was simple, it was understandable [...] But if you were a panelist on a show for the military or if you were in the military or if you were a scholar who wanted to portray yourself as serious missile expert or defense expert, then you used SDI. So, you had the two terms there, and one represented the serious professionals who were building the system and the other represented the general population." (Fitzwater, Marlin. 2017. Interview with author, October 31).

The inner-circle of proponents (Congressmen and other key Republican politicians) were initially also primarily concerned with counteracting the science-fictionalization that came with the Star Wars label. This becomes apparent in the first congressional budget debate related 
to SDI for fiscal year 1985, which would have been approved in 1984. Like Reagan, the (mostly Republican) proponents of SDI either refrained from using the term Star Wars, instead referring to the Strategic Defense Initiative or SDI, or actively argued against it (Congressional Record June 13, 1984). Dan Quayle (R-IN), for example, said "I know there is a lot of momentum out there to say we have to do something about this, keep referring to 'Star Wars.' That is strictly a defensive initiative. We are talking about defensive weapons, not offensive weapons" (p. 16122). Former Congressman AuCoin (D-OR) recalls the Star Wars label's ridicule effect on SDI proponents: "They were miffed, huffy, got very huffy when the Star Wars reference was used on the floor in Congress. They would say in a self-righteous way: SDI the Strategic Defense Initiative" (AuCoin, Les. 2017. Interview with author, October 31).

SDI proponents, in turn, leveraged the Strategic Defense Initiative label to pressure opponents into approving funding: "I received direct mail from Republican majority leaders who accused Democrats of not supporting the Strategic Defense Initiative, with Defense in italics. People couldn't understand the intricacies and it was difficult to be against defense." (AuCoin, Les. 2017. Interview with author, October 31).

The contrasting meanings and effects that came with the terms Star Wars and SDI also affected opponents. Bob Mrazek (D-NY) successfully proposed a bill to the House Appropriations Committee to curtail the administration's request for $\$ 1.77$ billion down to $\$ 1.09$ billion (Hiatt 1984). He made the conscious decision to refrain from labelling the project Star Wars when trying to convince Republicans to reduce funding:

"I did not want to be perceived as someone who was in a sense demonizing the program, not demonizing, but making fun of it, as opposed to working with those Republicans who I needed to vote with me to strike the funding, that I was being respectful. So, I consciously attempted to be respectful in the verbiage that I used with regard to the program." (Mrazek, Bob. 2017. Interview with author, November 2)

This perception, however, did not prevent Congressman Mrazek from believing in the enabling effect of popular culture in general. He used a carefully chosen scene from a movie to convince Reagan of SDl's flaws:

"I knew that the president had a particular fondness for General Patton [...] And so when I was presenting my case before the committee and the president and the vice president, I repeated that scene from the movie [Patton] and I said 'that's my concern, Mr. President, that we are talking about building a Maginot Line in space" (Mrazek, Bob. 2017. Interview with author, November 2).

Furthermore, there is much less talk about Star Wars than about SDI in congressional debates, relative to media coverage. In the budget debate on 4 June 1985, for instance, the term SDI was used 342 times, whereas Star Wars was only mentioned 71 times (Congressional Record June 4, 1985). This was even the case in the speeches of opponents 
who supported the most drastic budget reductions. This goes back to the main goal of congressional debates, which is to convince peers. Technical jargon is more likely to have this effect than a lofty popular culture reference. This may also explain why the acronym SDI was used far more often than the full name Strategic Defense Initiative. The fact that proponents and opponents consciously thought about whether to use the Star Wars label or not illustrates the disabling effect that came with science-fictionalization: Star Wars was so disliked by SDI proponents that even opponents refrained from using the label when trying to generate consensus. Furthermore, the ridicule that comes with science-fictionalization tainted the term in expert settings.

Despite proponents' success in replacing Star Wars with SDI in Congressional debates, Reagan's aversion for the Star Wars label persisted throughout his time in office. This became apparent when he vetoed the national defense authorization act for fiscal year 1989, remarking: "They say this bill would take the 'stars' out of Star Wars. With my veto today, I'm putting back the 'l' - initiative - in SDI." (Reagan, Ronald. 1988. Speech, August 3). For some senior administration officials, their dislike of the Star Wars label persists to this day. When audience members at a promotion of Former Director of the Arms Control and Disarmament Agency Kenneth Adelman's book, Reagan at Reykjavik, asked about Star Wars, he preferred to use the term SDI:

"Because it was the right name for it, it didn't have the mocking that like I say, Star Wars had, and when I was on interviews like on television, even when I was writing my book, I said SDI not Star Wars, because most people think of it as Star Wars. The Democrats and especially Ted Kennedy was effective enough to almost change the name of it, so I wanted to go back to the original." (Adelman, Kenneth. 2017. Interview with author, November 1).

However, not everyone played on or tried to evade the science-fictionalization that came with the Star Wars analogy. The Star Wars label had enabling aspects, too. White House press secretary Marlin Fitzwater, for example, also saw positive qualities in the label:

"You couldn't find a colloquial term that was more effective than Star Wars. It wasn't that it was accurate [...] but it was so effective and it had immediate meaning because the media used it so much that if you said Star Wars people knew immediately what you were talking about. And so in a sense it's very effective, like any branding kind of name, what you strive for is recognition by the population. And this had total recognition" (Fitzwater, Marlin. 2017. Interview with author, October 31).

Thus, one important enabling effect of Star Wars that helped proponents was the widespread name recognition that came with the term.

Moreover, some Reagan administration officials hoped that the popularity of the Star Wars franchise would be linked to the policy and help its popularity. Reagan's Assistant Secretary of Defense, Richard Perle, is quoted by FitzGerald $(2000,39)$ saying about the 
Star Wars label: "Why not? It's a good movie. Besides, the good guys won." In this vein, after saying "[w]e hate the Star Wars phrase", Lt-Gen Abrahamson, Director of the Strategic Defense Initiative Office, remarked "[h]owever, don't forget that in the movie the good guys won because the Force was on their side. I am convinced that the Force is with us" (Wavell and Cook 1986). Lt-Gen Abrahamson thus used the Star Wars label to tap into sentiments of patriotism and anti-Communism, which were prevalent at the time and appealed to diverse segments of American society (Reiss 1992, 157). The Star Wars label communicated that defending "good" was necessary and legitimate, given the threat emanating from the Soviet Union.

Linenthal's (1989) analysis and reprints of cartoons show that cartoonists used Star Wars to both question and endorse Reagan's SDI. This illustrates that works of science fiction can be interpreted in multiple ways and thus be used to communicate opposite viewpoints about norms and policies. However, these enabling efforts are the exception, rather than the rule when it comes to the SDI proponent's communication strategy. ${ }^{8}$ The above-mentioned perceptions that the Star Wars label invites trivialization and ridicule prevailed. Compared to the disabling effect, it took more than uttering the words "Star Wars" to build linkages to Star Wars that enabled the communication of SDI and overcame the negative aspects of sciencefictionalization.

The use of Star Wars influenced how politicians communicated their viewpoints. While some consciously argued against the science fiction analogy or refrained from using it, others tapped into its enabling potential. Reactions depended on whether decision-makers considered the use of popular cultural helpful in the pursuit of their goals. The science-fictionalization that came with the Star Wars label dominated the early years of debate, and could beseen in the reactions of key decision-makers. SDI proponents perceived the Star Wars label as undermining their case, and this perception influenced their own discursive strategies as well as those of SDI opponents. The introduction of the more professional term Strategic Defense Initiative, and its abbreviation SDI, helped mitigate this effect in expert settings. What helped in public debate was the widespread use of term, which stripped it of its negative connotations.

\section{Over time: The neutralizing effect}

The term Star Wars became at least as frequently used as SDI to refer to Reagan's vision of a space-based, nationwide missile defense system in the US and abroad. What contributed to

\footnotetext{
${ }^{8}$ Schlafly, Abrahamson and Perle are the only proponents trying to communicate SDI with Star Wars cited by scholars (Krämer 2012; Linenthal 1989; FitzGerald 2000) and that I know of.
} 
this widespread use of the Star Wars label was that the official name, SDI, was only introduced in 1984, almost a year after Reagan's original announcement (Reiss 1992, 73; Krämer 2012, 61). Moreover, Star Wars was a catchy term used to refer to Reagan's vision in the interim and beyond: "Star Wars is rich imagery and has more vivid appeal. SDI is more of a textbook kind of term, where the public eye starts glazing over it" (AuCoin, Les. 2017. Interview with author, October 31). Star Wars was also a catchy term to refer to the missile defense system because of the links to Reagan's personality, the popularity of the Star Wars movies, and similarities between Star Wars and the actual policy proposal. The Star Wars imagery helped to simplify a complex issue. Furthermore, as Bloomfield (2016) observed, proponents and opponents of new norms such as SDI needed to respectively show, or disprove, viability and normative desirability. Proponents succeeded in sufficiently persuading the public and their peers of both in following years. If this had not been the case, the missile defense system would have disappeared quickly from public discourse, preventing the widespread use of the Star Wars label that eventually neutralized its disabling effect.

Through content analysis of newspaper articles and congressional records, the next section illustrates that the Star Wars label was very widely used. This trend ultimately led to the undoing of its disabling effect, particularly among the public.

\section{Analysis of newspaper articles: Widespread use}

To trace the use of the term Star Wars in the debate over SDI, I collected data on its use in The Wall Street Journal (WSJ), The New York Times (NYT), and The Washington Post (WP) from 1984 to 1988. These newspapers were selected because of their large readership and different political leanings. The searches in Table 1 are from the timeframe between January 1, 1984 and December 31, 1988. The WSJ archive is only available from 1984 onwards. While Reagan announced the idea of a space-based missile defense shield on 23 March 1983, it did not become a major point of public discussion until Reagan requested a major budget increase for the policy in 1985 (FitzGerald 2000, 211-212). Thus, the search results for NYT and WP changed insignificantly when 1983 was incorporated.

Table 1 reflects these dynamics: discussion over Reagan's missile shield peaked in 1985, which is considered as the most successful year for SDI proponents. At this point, Strategic Arms Reduction Talks (START) had resumed in Geneva, and this was attributed to Star Wars (WP, Rosenfeld 1985 and Oberdorfer 1985). This success showed signs of the viability and purpose of SDI, and was an important reason for Congress nearly doubling SDI funding for fiscal year 1986, to USD 2.9 billion (Reiss 1992, 92). When discussion peaked, the Star Wars 
and Strategic Defense Initiative labels were often used together. This indicates that Star Wars and 'Strategic Defense Initiative became interchangeable terms, but also that clear signs of policy success were necessary to keep Star Wars on the political agenda.

The Star Wars label was most frequently used in isolation during 1984 and 1985, but its use declined in comparison to Strategic Defense Initiative in later years. Particularly in 1986 and 1987 , the term Strategic Defense Initiative caught up and was used more often on its own than Star Wars was. The outlier is the NYT. While over the years the terms Star Wars and Strategic Defense Initiative were used with similar frequency on their own in the WSJ and WP, the NYT used the term Star Wars about three times more than Strategic Defense Initiative. This may indicate that the NYT was more critical of the policy.

The Reagan administration's failure to introduce a (catchy) alternative term in a timely manner was an important reason for the persistence of the Star Wars label. Since the name Strategic Defense Initiative was only introduced in early 1984, Star Wars was the only short-hand in months prior. This first-mover advantage explains why the term was used more frequently in the beginning, but it may also have contributed to its persistent use more generally. A significant number of articles included the explanation that the "Strategic Defense Initiative" (WSJ, Carrington and Fialka 1986), the "anti-missile system" (WSJ, Birnbaum 1988), or the "space defense program" (NYT, Schmemann 1986) was "known as Star Wars" or even "called Star Wars" (WSJ, Carrington 1985). This illustrates how well-established the Star Wars label became. A closer look at the newspaper articles in the next section reveals that the widespread use of the Star Wars label neutralized the very term's meaning in public use. It became a description for the policy.

Three factors thus facilitated the widespread use of the Star Wars label, and led to its neutralization: the Reagan administration's failure to introduce a (catchy) name for the policy in a timely manner; linkages between Star Wars and the policy; and changing perceptions of viability that kept the discussion over the policy alive. I highlight the relevance of these three factors by comparing the widespread use of the Star Wars label to a specific case where widespread popular use also turned an analogy with a ridiculing effect into a descriptive shorthand: the debate over the big bang theory. 
Table 1: Search results for terms "Star Wars" AND/OR "Strategic Defense Initiative" in US newspapers

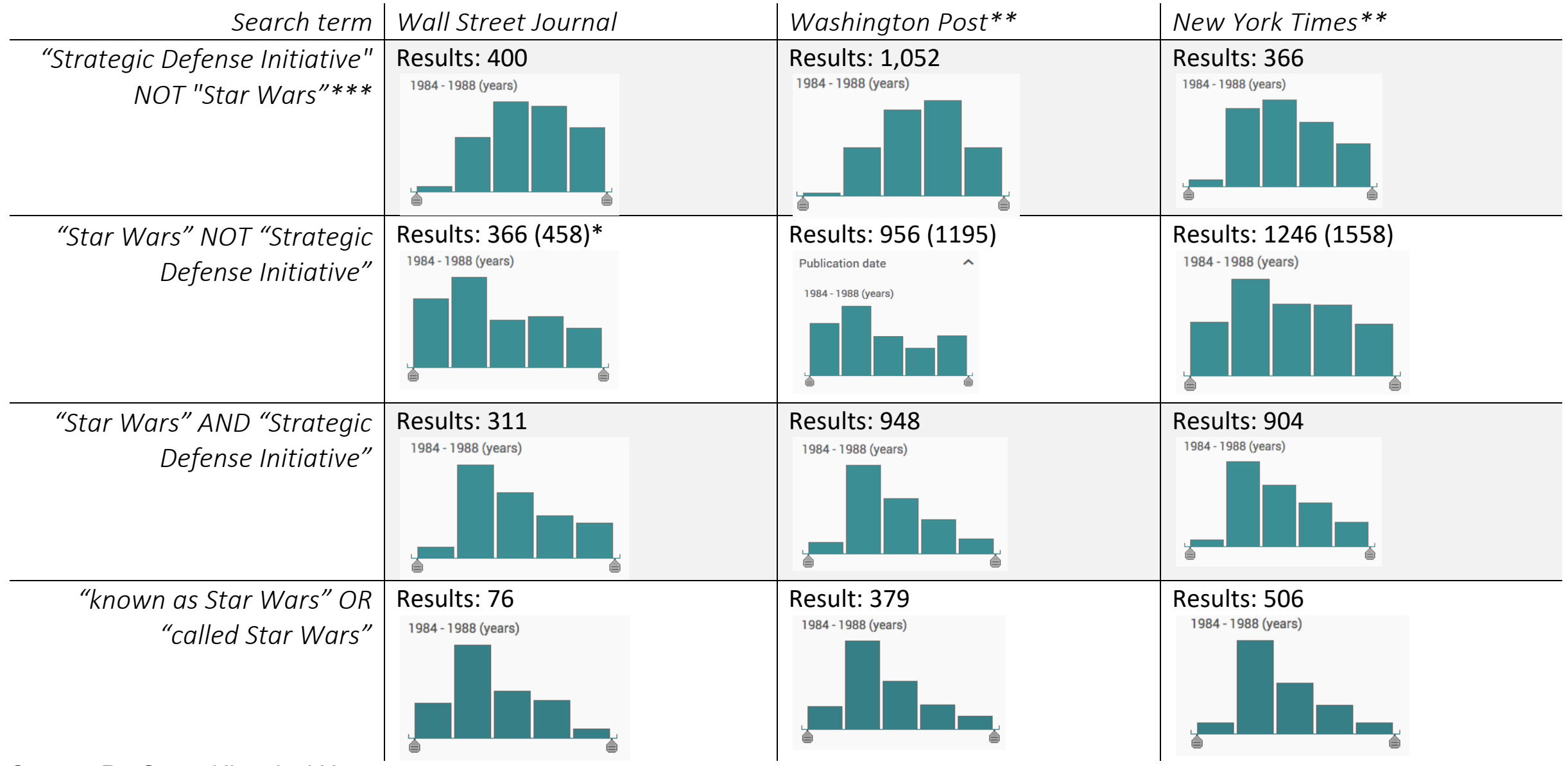

Source: ProQuest Historical Newspapers

* When searching for Star Wars, articles on topics other than SDI were included when controlling for both "movie" and "Strategic Defense Initiative". A search of the term "Star Wars" with/without "movie" and randomized checks lead to the conclusion that about $20 \%$ of all articles are about the movie rather than about SDI. The unadjusted result is in brackets.

**In the Washington Post and New York Times, I only searched in 'front page articles', 'articles' and 'editorials' (including other newspaper parts such as classified ads led to inaccurate results). In the WSJ archive, such a preselection is not possible, but the results are limited to articles.

***The acronym SDI was rarely used on its own; 'Strategic Defense Initiative" search results include almost all SDI results and are the same when in lower capitals 
Like Reagan, the founders of the big bang theory failed to give a name or phrase to their theory. An opponent of the theory, one of the founders of the rival steady state theory, Fred Hoyle, coined the term when giving a series of BBC radio broadcasts a few years later (Kragh 2013). While Kragh (2013) rejects the conventional wisdom that Hoyle intended to ridicule big bang theory, it becomes clear from his discussion that the big bang label did in fact have such an effect. Gamow, one of the founders of the big bang theory, resented it and scientists dislike it to this day. Moreover, the vivid picture of an explosion that the term big bang conveys contrasts it to the theory of a steady state, a simplification and link to the theories that Hoyle considered important when discussing complex issues on the radio (quoted in Lightman and Brawer 1990, 60). Because of a lack of evidence of a big bang between the 1940s and the 1960s, the theory was not discussed much. The label only caught on once the viability of the theory was put on more solid footing when the discovery of cosmic microwave background radiation provided evidence of the expansion of the early universe. Therefore, just like in the debate over Star Wars, showing viability was important for the discussion to continue and for the big bang label to become widely used. There is a further similarity between the effects of the big bang and Star Wars labels. Kragh (2013) explains that the big bang term is popular and used descriptively by the press and public, but that scientists dislike the term because they consider the explosion metaphor misleading. This is very similar to how Reagan felt about the literal meaning of Star Wars, which he considered misleading. Scientists also regard the big bang term undignified and insufficiently serious. Despite efforts to replace the name (Sky and Telescope received 13099 suggestions when trying to find a suitable alternative in 1993), the big bang label has stuck to this day (Kragh 2013, 2.29)

\section{Analysis of newspaper articles: The neutralizing effect}

To show that the widespread media use of the Star Wars label neutralized its meaning, I compare the use of Star Wars in the NYT and the WSJ since they had the most divergent findings on the number of uses of Strategic Defense Initiative and Star Wars, and have different political leanings.

From each newspaper, I randomly selected ten articles from each year of the search results, using the following terms: "Star Wars" NOT "Strategic Defense Initiative" and "Star Wars" AND "Strategic Defense Initiative" (the random selection generated 200 articles) ${ }^{9}$. As opinion polls reveal, the Star Wars label has a disabling effect on public opinion, when parallels between negative aspects of the movie (title) and of the missile defense system are drawn. Thus, I coded whether the Star Wars label was used to highlight criticism or praise (e.g. as analogy

\footnotetext{
${ }^{9}$ The newspaper articles are on file with the author and can be shared upon request.
} 
or word play), or if it was used descriptively as a name for the policy but not in reference to the tone of the article itself (positive or negative with respect to the policy). Table 2 gives an overview. The term was mainly used descriptively, regardless of the newspaper and of whether it was used on its own or together with Strategic Defense Initiative. The disabling effect of Star Wars was neutralized.

Table 2: The use of the Star Wars label over time "Star Wars" NOT "Strategic Defense Initiative"

\begin{tabular}{|l|l|l|l|l|l|l|l|l|}
\hline \multicolumn{3}{|l|}{ Descriptive } & \multicolumn{2}{l|}{ Negative } & \multicolumn{2}{l|}{ Positive } & \multicolumn{2}{l|}{$\begin{array}{l}\text { Unrelated } \\
\text { articles }^{10}\end{array}$} \\
\hline & WSJ & NYT & WSJ & NYT & WSJ & NYT & WSJ & NYT \\
\hline 1984 & 7 & 5 & 2 & 5 & & & 1 & \\
\hline 1985 & 6 & 7 & 1 & 2 & 1 & & 2 & 1 \\
\hline 1986 & 9 & 8 & & & & & 1 & 2 \\
\hline 1987 & 7 & 6 & & 2 & 1 & & 2 & 2 \\
\hline 1988 & 8 & 7 & & 2 & & & 2 & 1 \\
\hline
\end{tabular}

"Star Wars" AND "Strategic Defense Initiative"

\begin{tabular}{|l|l|l|l|l|}
\hline \multicolumn{2}{|l|}{ Descriptive } & \multicolumn{2}{l|}{ Negative } \\
\hline & WSJ & NYT & WSJ & NYT \\
\hline 1984 & 9 & 8 & 1 & 2 \\
\hline 1985 & 10 & 9 & & 1 \\
\hline 1986 & 9 & 9 & 1 & 1 \\
\hline 1987 & 10 & 10 & & \\
\hline 1988 & 8 & 10 & 2 & \\
\hline
\end{tabular}

In 1984 there was a tie in the NYT between the descriptive and disabling use of Star Wars, when the term was used on its own. This largely goes back to the fact that the NYT directly quoted political opponents or invited them to write a guest contribution, which sciencefictionalized the policy. For instance, Congressman Stark (1984) wrote: "Star Wars' are still wars. They must be avoided" and called the policy the "President's 'Star Wars' fantasy." Democratic candidate Walter Mondale (New York Times 1984) referred to Star Wars as a "fairy tale."

${ }^{10}$ This supports my finding (see table 1) that roughly $20 \%$ of the former, 'Star Wars' only, search results are not related to missile defense 
Most direct quotes were printed in 1984. The policy was still new and merely a proposal, which is when we would expect opponents to make most use of popular culture's disabling effect. Furthermore, it was an election year, when politicians were given more of a platform than in other years. In fact, the negative Star Wars articles in 1988 also go back to direct quotes by politicians opposed to Reagan's missile defense, such as Les Aspin and Dukakis (WSJ, Seib 1988a, McQueen and Carrington 1988; NYT, Weinraub 1988). Interviews and direct quotes in newspaper articles indicate that, on the contrary, inner-circle proponents of Reagan's SDI refrained from using Star Wars (Weinraub 1984; Millers 1987). However, sometimes journalists also mobilized the disabling - or enabling - effect of Star Wars, discussing the "Dark side of 'Star Wars'" (Boffey 1985) or the "'star wars' arms race-threat" (Wall Street Journal 1984a), although this was not as frequent.

Even when only the term Star Wars was used in an article, it was mainly employed as a descriptive short-hand for the policy in both newspapers (NYT, Safire 1985; Chiras 1977; WSJ, Shafer 1987; Wall Street Journal 1984b). For example, Shafer (1987) wrote that "[s]ome Reaganites predict Senate Democrats will use a filibuster to try to get White House concessions on other issues, such as Star Wars." This neutralization also occurred when both terms were used in the same article. Often, the only mention of the two terms was in the explanation that the Strategic Defense Initiative was known as or called Star Wars (e.g. WSJ, Carrington and Fialka 1986; NYT, Schmemann 1986). In many articles in both newspapers, the term Star Wars was mentioned more often than Strategic Defense Initiative or SDI when both terms were used together, which indicates the popular appeal of the Star Wars label (WSJ, Read 1988; Seib 1988b; NYT, Halloran 1986; Weinraub 1984; Apple 1985).

This illustrates that the success of the analogy led to the undoing of the disabling effect: the Star Wars label became widely used as vernacular, rather than as a vehicle for communicating criticism. Following Wittgenstein $(1973,43)$, words do not have pre-given but contextual meanings. Consequently, the context in which the label was used, i.e. if the journalist was writing in favor of or against Star Wars, disabled or enabled the communication of the missile defense system, rather than the use of the popular culture reference to this effect.

As in newspaper articles, we can also identify the neutralizing effect of the popular culture reference's widespread public use in congressional debates. In 1984, proponents of the missile defense system still tried to counteract the disabling effect of Star Wars and felt compelled to argue against the term (Congressional Record June 13, 1984). A year later, however, they no longer felt the need to do so (Congressional Record June 4, 1985). When the term Star Wars was used on 4 June 1985, it was mainly employed as an 
interchangeable, descriptive term, next to Strategic Defense Initiative and SDI. For instance, Mitchell (D-ME) said "I will support cuts in the star wars budget proposed by the President. The technologies embraced by the strategic defense initiative deserve to be carefully and completely examined" (Congressional Record June 4, 1985, 14069). However, as described earlier, the Star Wars label was mainly replaced with the SDI label in congressional debates, rather than used alongside it as in newspaper articles, because SDI appeared more professional and less tainted.

\section{Conclusion}

The use of Star Wars in the debate over SDI illustrates that decision-makers adjust their communication strategies depending on whether they consider popular culture references as disabling or enabling the communication of their preferred policies. Initially, opponents built on linkages between the characteristics of Star Wars and Reagan's missile shield to sciencefictionalize the policy. This science-fictionalization then constituted the socio-political context in which politicians operated. I find that SDI proponents and opponents consciously reflected on whether using the Star Wars frame would help or hinder their goals. In expert settings, the introduction of the more professional term, SDI, mitigated this science-fictionalization. In public use, the widespread use of the popular culture reference neutralized the sciencefictionalization and it became used as a descriptive short-hand.

Studying whether and how actors use popular culture in debates over security policy, and the effects of such popular culture references, constitutes an important contribution to the study of global security, a subfield of international relations scholarship where fact and fiction blend together. The findings of this article raise interesting questions for future research: if the widespread use of popular culture leads to neutralization of its otherwise disabling effect, is popular culture then most effective when it is used sparingly as a rapid response device? Do actors try to prevent widespread use? Furthermore, the findings also invite further study of scope conditions. It would be instructive, for instance, to compare cases where the disabling effect of popular cultural references stems from use of popular culture per se, and those where disabling effects are tied more to a particular reference's literal meaning. Do these differences affect the impact of disabling effects? As the debate over the big bang theory shows, further research is also warranted to investigate whether disabling, enabling, and neutralizing effects are indeed as unique to popular culture as scholars have made them out to be, or if they more broadly apply to analogies and metaphors. 


\section{Bibliography}

Adelman, Kenneth L. 2017. (Director of the U.S. Arms Control and Disarmament Agency (1983-1987)). Phone interview with author. November 1.

Apple Jr, Raymond W. 1985. "Britain Questions 'Star Wars' Plan: Foreign Secretary, in Speech, Asks If Project Could Work." The New York Times, March 16.

AuCoin, Walter Leslie "Les". 2017. (Member of the U.S. House of Representatives (D-OR) (1975-1993)). Phone interview with author. October 31.

Benford, Robert D., and David A. Snow. 2000. "Framing Processes and Social Movements: An Overview and Assessment." Annual Review of Sociology 26: 611-39.

Birnbaum, Jeffrey H. 1988. "Campaign '88: Jack Kemp, High in Spirit but Low in the Polls, Frees His Mind on the Stump as Early Tests Loom." The Wall Street Journal, February 2.

Bloomfield, Alan. 2016. "Norm Antipreneurs and Theorising Resistance to Normative Change." Review of International Studies 42 (2): 310-333.

Bob, Clifford. 2012. The Global Right Wing and the Clash of World Politics. New York: Cambridge University Press.

Boffey, Philip M. 1985. "Dark Side of 'Star Wars': System Could Also Attack: Shield's Dark Side: It Could Also Attack Weapons in Space/Offensive Potential." The New York Times, March 7.

Boyer, Paul S. 2011. "Selling Star Wars: Ronald Reagan's Strategic Defense Initiative." In Selling War in a Media Age: The Presidency and Public Opinion in the American Century, edited by Kenneth Osgood, Andrew K. Frank, and David Halberstam, 196223. Gainesville: University Press of Florida.

Box Office Mojo. 2017a. "Star Wars." Accessed December 1, 2017, http://www.boxofficemojo.com/movies/?id=starwars4.htm

Box Office Mojo. 2017b. "All Time Box Office. Domestic Grosses." Accessed, December 1, 2017, http://www.boxofficemojo.com/alltime/adjusted.htm

Box Office Mojo. 2017c. "The Empire Strikes Back." Accessed December 1, 2017, http://www.boxofficemojo.com/movies/?id=starwars5.htm

Busby, Joshua W. 2007. "Bono Made Jesse Helms Cry: Jubilee 2000, Debt Relief, and Moral Action in International Politics." International Studies Quarterly 51 (2): 247-75.

Cannon, Lou. 1983. "President Seeks Futuristic Defense Against Missiles." The Washington Post, March 24.

Carrington, Tim. 1985. "Weinberger Defends Defense Budget but Senators Say Request Will be Cut." The Wall Street Journal, February 5.

Carrington, Tim, and John J. Fialka.1986. "Reagan Appeals to Nation to Shore Up Waning Support for Military Buildup." The Wall Street Journal, February 27.

Carpenter, Charli. 2016. "Rethinking the Political / -Science- / Fiction Nexus: Global Policy Making and the Campaign to Stop Killer Robots." Perspectives on Politics 14 (1): 5369.

Checkel, Jeffrey T. 1999. "Norms, Institutions, and National Identity in Contemporary Europe." International Studies Quarterly 43 (1): 84-114.

Chiras, Susan. 1987. "Japanese Role In 'Star Wars' May Be Small.” The New York Times, July 22.

U.S. Congress. Congressional Record. $98^{\text {th }}$ Congress, $1^{\text {st }}$ session, March 24, 1983. Vol. 129 , pt. 6: 7096-7534.

U.S. Congress. Congressional Record. $98^{\text {th }}$ Congress, $2^{\text {nd }}$ session, June 13,1984 . Vol. 130 , pt. 12: 16003-16338.

U.S. Congress. Congressional Record. $99^{\text {th }}$ Congress, $1^{\text {st }}$ session, June 4,1985 , Vol. 131 , pt. 10: $13964-14265$.

Der Derian, James. 2009. Critical Practices in International Theory: Selected Essays. London; New York: Routledge. 
Desloge, Nick. 2012. "Star Wars: An Exhibition in Cold War Politics." In Sex, Politics, and Religion in Star Wars: An Anthology, edited by Douglas Brode and Leah Dyneka, 55-62. Lanham, MD: Scarecrow Press.

Dicks, Norman DeValois "Norm". 2017. (Member of the U.S. House of Representatives (DWA) (1977-2013)). Phone interview with author. October 30.

Finnemore, Martha, and Kathryn Sikkink. 1998. "International Norm Dynamics and Political Change." International Organization 52 (4): 887-917.

FitzGerald, Frances. 2000. Way out There in the Blue: Reagan and Star Wars and the End of the Cold War. New York: Simon \& Schuster Ltd.

Fitzwater, M. Marlin. 2017. (White House deputy press secretary (1983-1985) and White House press secretary (1987-1993)). Phone interview with author. October 31.

Graham, Thomas W., and Bernard M. Kramer. 1986. "The Polls: ABM and Star Wars: Attitudes Toward Nuclear Defense, 1945-1985." The Public Opinion Quarterly 50 (1): 125-34.

Griffin, Penny. 2015. Popular Culture, Political Economy and the Death of Feminism: Why Women Are in Refrigerators and Other Stories. Popular Culture and World Politics. London: Routledge.

Halloran, Richard. 1986. "Bonn Urges New Missile Defense." The New York Times, February 10.

Hiatt, Fred. 1984. "House Panel Revives Restriction; Curb Voted on U.S. Troops in Latin America." The Washington Post, September 27.

Jupille, Joseph, Walter Mattli, and Duncan Snidal. 2013. Institutional Choice and Global Commerce. New York: Cambridge University Press.

Katzenstein, Peter J. 1996. The Culture of National Security: Norms and Identity in World Politics. New York: Columbia University Press.

Kennedy, Kevin C. 1986. "Treaty Interpretation by the Executive Branch: The ABM Treaty and 'Star Wars' Testing and Development." The American Journal of International Law 80 (4): 854-77.

Kiersey, Nicholas J., and Iver B. Neumann. 2013. "Introduction: Circulating on Board the Battlestar." In Battlestar Galactica and International Relations, edited by Nicholas J. Kiersey and Iver B. Neumann, 1-17. London: Routledge.

Kragh, Helge. 2013. "Big Bang: The Etymology of a name" Astronomy \& Geophysics 54 (2): 2.28-2.30.

Krämer, Peter. 2012. "Fighting the Evil Empire: Star Wars, the Strategic Defense Initiative, and the Politics of Science Fiction." In Sex, Politics, and Religion in Star Wars: An Anthology, edited by Douglas Brode and Leah Dyneka, 63-76. Lanham, MD: Scarecrow Press.

Krook, Mona Lena, and Jacqui True. 2012. "Rethinking the Life Cycles of International Norms: The United Nations and the Global Promotion of Gender Equality." European Journal of International Relations 18 (1): 103-27.

Legro, Jeffrey W. 2000. "The Transformation of Policy Ideas." American Journal of Political Science 44 (3): 419.

Lightman, Alan, and Roberta Brawer. 1990. Origins: The Lives and Worlds of Modern Cosmologists. Cambridge, MA: Harvard University Press.

Linenthal, Edward. 1989. Symbolic Defense: The Cultural Significance of the Strategic Defense Initiative. Urbana: University of Illinois Press.

Lockheed, Martin. n.d. "Striking a Bullet with a Bullet: HOE." Accessed, December 1, 2017, http://www.lockheedmartin.co.uk/us/100years/stories/hoe.html

McQueen, Michel and Tim Carrington. 1988. "Dukakis, With Tougher Tone on Defense, Pledges Support for Weapons Systems. The Wall Street Journal, September 15.

Meyer, David S. 1992. "Star Wars, Star Wars, and American Political Culture1." The Journal of Popular Culture 26 (2): 99-115.

Millers, Judith. 1987. "'Sometimes I Say Things Differently." The New York Times, March 23. 
Neumann, Iver B., and Daniel H. Nexon. 2006. "Introduction: Harry Potter and the Study of World Politics." In Harry Potter and International Relations, edited by Iver B.

Neumann and Daniel H. Nexon. Lanham, MD: Rowman \& Littlefield Publishers, Inc.

Mrazek, Robert Jan "Bob". 2017. (Member of the U.S. House of Representatives (D-NY) (1983-1993)). Phone interview with author. November 2.

Oberdorfer, Don. 1985. "Shultz, Gymko Agree to Discuss Space Weapons: U.S.-Soviet Arms Negotiations to Resume." The Washington Post, January 11.

Pifer, Steven. 2015. "The Limits of U.S. Missile Defense." The Brookings Institution. Accessed, December 1, 2017.

http://www.brookings.edu/research/opinions/2015/03/30-us-missile-defense-limitspifer.

Price, Richard. 1998. "Reversing the Gun Sights: Transnational Civil Society Targets Land Mines." International Organization 52 (3): 613-44.

Ronald Reagan Presidential Library. 2017. "The Public Papers of President Ronald W. Reagan". Accessed, December 1, 2017, https://reaganlibrary.gov/sspeeches

Read, Eileen W. 1988 "Lockheed to Tap Ex-Pentagon Official For War Technology Unit, Sources Say." The Wall Street Journal, August 5.

Reagan, Ronald W. 1983. "Remarks at the Annual Convention of the National Association of Evangelicals in Orlando, Florida." Speech. March 8. Accessed, December 1, 2017, https://reaganlibrary.gov/sspeeches

Reagan, Ronald W. 1983. "Address to the Nation on Defense and National Security." Speech. March 23. Accessed, December 1, 2017, https://reaganlibrary.gov/sspeeches

Reagan, Ronald W. 1985. "Written Responses to Questions Submitted by Hurriyet of Turkey." Speech. March 29. Accessed, December 1, 2017, https://reaganlibrary.gov/sspeeches

Reagan, Ronald W. 1985. "Remarks at a State Republican Fundraising Luncheon in Parsippany, New Jersey." Speech. October 4. Accessed, December 1, 2017, https://reaganlibrary.gov/sspeeches

Reagan, Ronald W. 1985. "Remarks in an Interview with Representatives of Soviet News Organizations, Together With Written Responses to Questions." Speech. October 31. Accessed, December 1, 2017, https://reaganlibrary.gov/sspeeches

Reagan, Ronald W. 1986. "Remarks to Representatives of the Young Astronauts Council on Their Departure for the Soviet Union." Speech. October 16. Accessed, December 1, 2017, https://reaganlibrary.gov/sspeeches

Reagan, Ronald W. December 11, 1987. "Remarks and a Question-and-Answer Session With News Editors and Broadcasters." Speech. December 11. Accessed, December 1, 2017, https://reaganlibrary.gov/sspeeches

Reagan, Ronald W. 1988. "Remarks on the Veto of the National Defense Authorization Act, Fiscal Year 1989, and a Question-and-Answer Session with Reporters." Speech. August 3. Accessed, December 1, 2017, https://reaganlibrary.gov/sspeeches

Reiss, Edward. 1992. The Strategic Defense Initiative: The Development of an Armaments Programme. Cambridge: Cambridge University Press.

Rosenfeld, Stephan S. 1985. "Reagan's Geneva Success." The Washington Post, January 11.

Safire, William. 1985. "The Fireside Summit: Reviewing the Success Checklist." The New York Times, November 21.

Sandholtz, Wayne. 2008. "Dynamics of International Norm Change: Rules against Wartime Plunder." European Journal of International Relations 14 (1): 101-31.

Schimmelfennig, Frank. 2001. "The Community Trap: Liberal Norms, Rhetorical Action, and the Eastern Enlargement of the European Union." International Organization 55 (1): 47-80.

Schmemann, Serge. 1986. "Gorbachev offers to scrap a-arms within 15 years: Renews test moratorium but he insists that Americans renounce 'Star Wars' - Reagan to study 
plan." The New York Times, January 6.

Shafer, Ronald G. 1987. "A Special Weekly Report From The Wall Street Journal's Capital Bureau." The Wall Street Journal, September 18.

Seib, Gerald F. 1988a. "Reagan Vetoes Defense Bill, Cites SDI Cuts." The Wall Street Journal, August 4.

Seib, Gerald F. 1988b. "Quayle Might Bring Hard-Line Slant To A Bush Government's Deliberations." The Wall Street Journal, August 22.

Shepherd, Laura J. 2013. Gender, Violence and Popular Culture: Telling Stories. Popular Culture and World Politics. New York: Routledge.

Stark, Fortney H. (Pete). 1984. "Avoiding 'Star Wars'." The New York Times, February 1.

Talbott, Strobe. 1988. The Master of the Game: Paul Nitze and the Nuclear Peace. New York: Knopf.

Thelen, Kathleen. 1999. "Historical Institutionalism in Comparative Politics." Annual Review of Political Science 2 (1): 369-404.

The New York Times. 1984. "On the Record: Mondale on Space Weapons." April 25.

The New York Times. 1983. "Nuclear Facts, Science Fiction." March 27.

The Wall Street Journal. 1984a. "World-Wide: [4]" June 15.

The Wall Street Journal. 1984b. "REVIEW \& OUTLOOK (Editorial): Spacey" July 6.

United Press International. 1983. "Washington News" March 24.

Wavell, Stuart and Cook, Stephen. 1986. "Wednesday people: Forcing the SCI pace/Lt-Gen James Abrahamson, director of the Strategic Defense Initiative." The Guardian, February, 19.

Weinraub, Bernard. 1984. "Thatcher Sees No Differences On 'Star Wars': Meets Reagan and Says She Backs Research." The New York Times, December 23.

Weinraub, Bernard. 1988. "Democratic Candidates Spar Over Budget Issues." The New York Times, May 26.

Weldes, Jutta. 2003. "Popular Culture, Science Fiction, and World Politics: Exploring Intertextual Relations." In To Seek out New Worlds: Science Fiction and World Politics, edited by Jutta Weldes, 1-30. New York; Basingstoke: Palgrave Macmillan.

Wendt, Alexander. 1992. "Anarchy Is What States Make of It: The Social Construction of Power Politics." International Organization 46 (2): 391-425.

Wendt, Alexander, and Raymond Duvall. 2008. "Sovereignty and the UFO." Political Theory 36 (4): 607-33.

Wiener, Antje, and Uwe Puetter. 2009. "Quality of Norms Is What Actors Make of It CriticalConstructivist Research on Norms, The." Journal of International Law \& International Relations 5 (1): 1-16.

Wittgenstein, Ludwig. 1973. Philosophical Investigations. Translated by Anscombe, Gertrude E. M. Oxford: Wiley-Blackwell. 